\title{
MODEL PEMURIDAN KONSELING BAGI ALUMNUS PERGURUAN TINGGI LULUSAN BARU (FRESH GRADUATE) YANG MENGINGKARI PANGGILAN PELAYANAN
}

\author{
Oleh : \\ ${ }^{* 1}$ Yuliati dan ${ }^{* 2}$ Kezia Yemima \\ ${ }^{*}$ Dosen Tetap STT Gamaliel \\ ${ }^{* 2}$ Dosen Tetap STT Gamaliel \\ Email: ${ }^{* 1}$ tyuliati@stt-gamaliel.ac.id, ${ }^{* 2}$ keziayemima@stt-gamaliel.ac.id
}

\begin{abstract}
ABSTRAK - Masyarakat Ekonomi ASEAN (MEA) berdampak bagi negara-negara ASEAN, termasuk Indonesia, karena mereka bebas bersaing untuk mengisi sektor tenaga kerja di seluruh negara ASEAN. Alumnus baru perguruan tinggi atau fresh graduate akan terimbas dampak MEA dalam bersaing mencari pekerjaan. Hal itu juga memunculkan permasalahan baru bagi fresh graduate terkait panggilan pelayanannya. Tujuan dari penelitian ini adalah untuk mengetahui pemuridan konseling bagi alumnus baru perguruan tinggi yang mengingkari panggilan pelayanannya. Penelitian menggunakan pendekatan kualitatif dan dianalisis dengan menggunakan analisis interaktif. Pengumpulan data menggunakan studi literatur dan wawancara lapangan terbatas. Hasil dari penelitian ini adalah model pemuridan konseling bagi alumnus perguruan tinggi lulusan baru yang mengingkari panggilan pelayanannya berdasarkan penjelasan prinsip, langkahlangkah dan dampak yang diharapkan.
\end{abstract}

Kata kunci : Pemuridan, Kontekstual, Yesus, Konseling.

ABSTRACT - AEC has an impact into the Asean country to freely competition for fulfill the workers in all Asean country. Asean Economic Community (AEC) has a great impact for the economy matters in Indonesia. The new alumnus from the High Scool or called fresh graduate will be impact because of AEC in the jobs seeker matter. According of the global competition of the ways of think the fresh graduate in the jobs seeker matter, it come a new problems about his ministry calling. The aims of the research was to knew about the conseling discipleship for the fresh graduate of the high school that denied his calling. The aim of this research to knew counseling discipleship for the fresh gradute of the high School that denied his calling. The approach of this research was used qualitative method. The analysis of this research used interactive analysis. Data's was captured with book study and field limited study. The result of this research is model counseling discipleship for the fresh graduated that denied his calling that discribe with principle, method, and the effect that be expected.

Kata kunci : Dicipleship, Contextual, Jesus, Counseling, CBG. 


\section{Latar Belakang Masalah}

Liberalisme ekonomi berpendapat, beberapa elemen pada pemikiran liberal mencakup pemikiran penting bahwa ekonomi pasar adalah sumber utama kemajuan, kerja sama, dan kesejahteraan. Campur tangan politik dan peraturan Negara dianggap tidak ekonomis dan malah menciptakan kemunduran serta memicu timbulnya konflik. ${ }^{1}$ Hal ini mendorong timbulnya tantangan global yang ada di depan mata yaitu, ASEAN Economic Community (AEC) yang diselenggarakan tahun 2015 yang mengisyaratkan adanya liberalisasi perdagangan barang, jasa, investasi, tenaga kerja terampil secara bebas, dan arus modal yang bebas. ${ }^{2}$

\section{ASEAN Economic Community}

(AEC) atau lebih dikenal dengan Masyarakat Ekonomi ASEAN (MEA) memiliki dampak besar bagi perekonomian di Indonesia. Berbagai penelitian mengenai MEA diantaranya, Pengaruh MEA terhadap pembangunan di Indonesia ${ }^{3}$, Dampak MEA terhadap pertumbuhan UMKM di Provinsi Riau ${ }^{4}$ Penguatan

${ }^{1}$ R.Jackson and G. Sorensen. Pengantar Studi Hubungan Internasional (terjemahan dari Introduction to International Relations). (Yogyakarta: Pustaka Pelajar, 2009),234-235

${ }^{2}$ Bella Amallia, "Dampak Asean Economic Community (Aec) Terhadap Tenaga Kerja Indonesia Di Singapura.” Jurnal JOM FISIP, Vol 4, No 2, 2017.

${ }^{3}$ Atep Abdu Rofiq, "Menakar Pengaruh Masyarakat EkonomiAsean 2015 Terhadap PembangunanIndonesia,"SalamJurnal Filsafat dan Budaya Hukum,2014, 251

${ }^{4}$ Yulia Delasari, ”Dampak Pasar Bebas Asean (Mea) Terhadap Pertumbuhan Umkm Provinsi Riau (Industri Makanan Bolu Kembojo)," Jurnal JOM Fisip, Vol 5, No 2, 2018, 1
Karakter Mahasiswa dalam menghadapi MEA, ${ }^{5}$ dan sebagainya. MEA menjadi fokus dan tantangan bagi dunia perekonomian di Indonesia.

MEA berdampak bagi berbagai negara di ASEAN yang bebas bersaing untuk mengisi sektor tenaga kerja di seluruh negara ASEAN. Bagi negara yang memiliki tenaga kerja dengan kualifikasi pendidikan dan kompetensi yang tinggi, MEA menjadi peluang untuk melakukan ekspansi tenaga kerja ke negara ASEAN lainnya. Untuk menghadapi persaingan yang sangat ketat dalam MEA ini, Indonesia harus mempersiapkan sumber daya manusia (SDM) yang terampil, cerdas, kreatif, dan kompetitif. Kondisi tersebut menuntut dunia pendidikan menghasilkan tenaga kerja yang produktif, inovatif, dan terdidik. ${ }^{6}$ Berdasarkan hal tersebut maka dituntut adanya komptensi tinggi bagi alumnus perguruan tinggi untuk dapat bersaing dalam persaingan tersebut.

Alumnus perguruan tinggi yang baru lulus atau fresh graduate akan terimbas dampak MEA dalam usaha persaingan dalam mencari pekerjaan. Beberapa penelitian mengenai fresh graduate dengan kaitannya terhadap dunia kerja diantaranya: Tingkat kecemasan Sarjana Fresh Graduate menghadapi Persaingan Kerja dan Pengangguran Intelektual, ${ }^{7}$ Pengaruh Jenjang

\footnotetext{
${ }^{5}$ Setuju, "Penguatan Karakter Mahasiswa dalam Menghadapi MEA", Seminar dan call For Papers, Dies Natalis Universitas Sarjanawiyata Tamansiswa ke-60, 2015, 1.

${ }^{6}$ Tri Astuti Arigiyati, Annis Deshinta Ayuningtyas, "Efektivitas Model Reciprocal Teaching BerdasarkanMotivasi Belajar Statistika Pada MahasiswaProdi Pgsd Fkip Ust"eminar dan call For Papers, Dies Natalis Universitas Sarjanawiyata Tamansiswa ke-60, 2015, 2-3.

${ }^{7}$ Nurmantika Wiji Sejati dan Rahmawati Prihastuti, “ Tingkat Kecemasan Sarjana Fresh Graduate menghadapi Persaingan Kerja dan Meningkatnya Pengangguran Intelektual," Jurnal Intuisi, Vol 4, No 3, 2012, 1.
} 
Karir dan Tantangan Pekerjaan Terhadap Minat Fresh Graduate FKIP Universitas Riau pada Profesi Sales, ${ }^{8}$ dan sebagainya. Penelitian mengenai Fresh graduate erat kaitannya dengan dunia kerja.

Berdasarkan dampak persaingan global terhadap paradigma alumuns baru dalam mencari pekerjaan muncul permasalahan baru yaitu bagi panggilan pelayanannya. Dampak ketatnya persaingan pencarian kerja akan membuat alumnus memilih fokus untuk tetap melayani Tuhan dalam pelayanan strategisnya atau hanya fokus pada bersaing dan bertahan hidup.

Pemuridan konseling adalah langkahlangkah seseorang menuju kemerdekaan dalam Kristus dan bukanlah sesi konseling yang tradisional. ${ }^{9}$ Alumnus baru perlu dimuridkan dan dikonseling saat menghadapi masalah yang membuat depresi, seperti ketatnya persaingan dalam pencarian dunia kerja. Membawa alumnus baru yang ingkar pada panggilan pelayanannya karena masalahmasalah pekerjaan di tengah tantangan global akan menjadi fokus dalam penelitian ini.

\section{Rumusan Masalah}

Berdasarkan latar belakang tersebut dapat ditarik suatu rumusan masalah penelitian yaitu: Bagaimana pemuridan konseling Kristen bagi alumnus baru perguruan tinggi yang mengingkari panggilan pelayanannya?

\section{Tujuan dan Manfaat Penelitian}

Tujuan dari penelitian ini adalah untuk mengetahui pemuridan konseling

\footnotetext{
${ }^{8}$ Kurniawaty Fitri, "Pengaruh Jenjang Karir dan Tantangan Pekerjaan Terhadap Minat Fresh Graduate FKIP Universitas Riau pada Profesi Sales," Jurnal Sosial Ekonomi Pembangunan, Vol 10, 2013, 119.

${ }^{9}$ Neil T. Anderson, Discipleship Counseling, (Malang: Gandum Mas, 2011), 157
}

bagi alumnus baru perguruan tinggi yang mengingkari panggilan pelayanannya. Manfaat yang diperoleh dari hasil penelitian ini adalah: pertama, membawa kembali alumnus-alumnus untuk tetap setia pada panggilan pelayanannya masing-masing; kedua, dapat mengatasi permasalahan alumnus baru terkait persaingan ketat dunia kerja dan penghidupannya sehingga dapat melihat pertolongan dan pernyertaan Tuhan dalam hdiupnya; ketiga, menolong alumnus untuk bertumbuh dan siap diutus bagi Kristus.

\section{Metode Penelitian}

Metodologi penelitian pada penelitian ini adalah menggunakan pendekatan kualitatif. $^{10}$ Analisis yang digunakan dalam penelitian ini adalah dengan menggunakan metode interaktif yaitu pengumpulan data, penyajian data, reduksi data dan penarikan kesimpulan. ${ }^{11}$ Pengumpulan data dilakukan dengan menggunakan sumber literatur pustaka dan penelitian ini juga melibatkan penelitian lapangan dengan wawancara ${ }^{12}$ yang dibatasi pada alumnus baru (fresh graduate) Persekutuan Mahasiswa Kristen Surakarta (PMKS).

\section{Pemuridan Konseling}

\footnotetext{
${ }^{10}$ Stevri Indra Lumintang dan Danik Astuti Lumintang, Theologia penelitian dan Penelitian Theologis science-ascience serta metodologinya, (Jakarta: Geneva Insani Indonesia, 2016), 99.

${ }^{11}$ M. B. Miles, \& Huberman, A. M. Qualitative Data Analysis: A Sourcebook of New Methods. (California. SAGE publications Inc, 1984), 23.

${ }^{12}$ Sugiyono, Metode Penelitian dan Pengembangan (Research and Development), (Bandung : Alfabeta, 2015),477-478.
} 
Pemuridan Konseling Menurut Yesus dengan Petrus dalam kaitannya dengan panggilan Pelayanan

Yesus memulai pelayanannya dengan proses rekrutmen orang-orang biasa untuk menjadi murid-Nya. Proses rekrutmen tersebut dilanjutkan kepada proses pemuridan. Kesinambungan proses rekrutmen dan pemuridan Yesus dapat dilihat dari 2 perikop Alkitab yaitu, Lukas 5:1-11 dan Yohanes 21:1-23.

Prinsip Yesus dalam memulai proses rekrutmen adalah pada ayat 10 . Yesus menanggapi pernyataan Petrus pada ayat 8, supaya Yesus meninggalkanya karena dia orang berdosa. Yesus meresponi pernyataan tersebut melalui kata "jangan takut, mulai dari sekarang", pernyataan tersebut menunjukkan adanya hubungan baru yang sedang dibuat oleh Tuhan Yesus dan murid-murid pertama terkhusus dengan Simon. Yesus memanggil Simon yang kewalahan dengan banyaknya ikan yang ditangkap untuk menjadi penjala manusia. ${ }^{13}$ Respons Simon yang merendahkan diri dan mengakui keberdosaannya memberikan dia anugerah kepada panggilan untuk menjadi penjala manusia. Setelah itu mereka meninggalkan perahunya untuk mengikut Yesus. $^{14}$ Namun setelah penyaliban Yesus, Petrus kembali ke perahunya dan baru benar-benar

\footnotetext{
${ }^{13}$ Robert Jamieson, et al, Commentary Critical and Explanatory on the Whole Bible, (Grand Rapid, MI : Christian Classics Ethereal Library,2009) 2103.

${ }^{14}$ Don Fleming, Bridge Way Bible Commentary, (Brisbane: Bridge Way Publication, 2005).443
}

meninggalkan kehidupan sekularnya setelah pentakosta. ${ }^{15}$

Yohanes 21 menceritakan kekecewaan para murid yang tidak mendapatkan ikan, namun di tepi pantai Tuhan Yesus memberikan mukjizat untuk melemparkan jala di sebelah kanan dan mendapatkan ikan 153 ekor. Hal ini menunjukkan providensia Allah. Setelah mukjizat itu Yesus berdiskusi dengan Simon. Yesus memanggil Petrus dengan sebutan "Simon”, bukan Petrus atau Kefas. Hal ini untuk mengingatkan panggilan pada saat pertama kali bertemu (Lukas 5:111). Yesus mengingatkan pada panggilan mula-mula dengan bertanya kepada Petrus sebanyak tiga kali. Hal ini dimaksudkan Yesus untuk menguji kesungguhan panggilan dari Petrus dan membuktikan providensia Allah. ${ }^{16}$

Langkah-langkah yang dilakukan Yesus dalam proses konseling dengan Simon Petrus adalah: pertama, penerimaan. Yesus menerima murid-murid yang pertama apa pun keadaannya. Yesus menanggapi penyesalan dosa Simon dengan penerimaan. ${ }^{17}$ Yesus menerima kembali saat murid putus asa dan kembali

\footnotetext{
${ }^{15}$ Robert Jamieson, et al, Commentary Critical and Explanatory on the Whole Bible, (Grand Rapid, MI : Christian Classics Ethereal Library,2009) 2104.

${ }^{16}$ Matthew Henry, Commentary on The Whole Bible Volume V (Matthew to John), ( Grand Rapid, MI : Christian Classics Ethereal Library, 2000), 1751-1754

${ }^{17}$ Robert Jamieson, et al, Commentary Critical and Explanatory on the Whole Bible, (Grand Rapid, MI : Christian Classics Ethereal Library,2009) 2103.
} 
kepada pekerjaan sekuler dengan memberikan mukjizat. ${ }^{18}$

Kedua, adalah langkah pendampingan. Yesus mendampingi dengan memberikan arahan bagi Simon, Yakobus, dan Yohanes dengan memberikan arahan untuk melemparkan jala ketika semalam-malaman mereka tidak mendapat ikan. ${ }^{19}$ Pendampingan ini tepat waktunya ketika mereka mengalami permasalahan Yesus datang sebagai sumber pemecahan masalah.Providensia Allah datang bersama pendampingan yang dilakukan Yesus. Lukas 5:1-11 dan Yohanes 21:1-23 menjelaskan proses keputusasaan dan kekecewaan karena tidak mendapat ikan. Pendampingan merupakan solusi Yesus bagi Simon.

Ketiga, langkah pengutusan. Yesus memberikan tugas panggilan pada Simon saat dipanggil pertama kalinya, dan Simon meresponinya. $^{20}$ Pada saat Yesus menampakkan diri dan mengujinya dengan pertanyaan, "Simon anak Yohanes, apakah engkau mengasihi Aku?" Tuhan Yesus memberi perintah untuk menggembalakan domba-domba-Nya. Tidak ada orang yang layak untuk pengutusan ini kecuali jika ia mengasihi Yesus dengan sungguhsungguh. $^{21}$

Berdasarkan hal tersebut maka Yesus mengutus Simon untuk melanjutkan

${ }^{18}$ Matthew Henry, Commentary on The Whole Bible Volume V (Matthew to John), ( Grand Rapid, MI : Christian Classics Ethereal Library, 2000), 1751.

${ }^{19}$ Don Fleming, Bridge Way Bible Commentary, (Brisbane: Bridge Way Publication, 2005).443

${ }^{20}$ Matthew Henry, Matthew Henry's Concise Commentary on The Bible, (Grand Rapids, MI: Christian Classics Ethereal Library, 2005)1203.

${ }^{21}$ Ibid, 1290. tugas pelayanan-Nya. Ketiga langkah ini menjadi hal utama Yesus yaitu penerimaan, pendampingan dan pengutusan.

Dampak konseling yang dilakukan oleh Tuhan Yesus kepada Simon adalah bahwa Simon siap mengikuti panggilan Yesus untuk melayani. Penderitaan, kesakitan, dan kematian akan muncul pada kehidupan orang Kristen yang berpengalaman sekalipun, tetapi dalam pengharapan akan kemuliaan Tuhan untuk meninggalkan keduniawian, untuk berjalan bersama Tuhan, Simon yang disebut Petrus memberikan diri untuk patuh dan mengikuti panggilan tersebut. Hal ini merupakan kehendak Kristus untuk setiap murid memikirkan tugas pelayanannya dan tidak kuatir akan kejadian di masa depan yang akan terjadi baik untuk dirinya sendiri atau orang lain. Banyak hal yang di dunia membuat orang pecaya cemas tetapi dalam panggilannya makah hal-hal tersebut tidak berarti apa-apa. ${ }^{22}$

\section{Pemuridan Konseling}

Prinsip pemuridan konseling adalah mengajak seseorang mengikuti langkah-langkah menuju kemerdekaan dalam Kristus dan bukanlah sesi konseling yang tradisional. Konselor sedang menfasilitasi pelayanan pendamaian sebagai duta bagi Kristus. Hal tersebut tidak menuntut karunia-karunia khusus, sebaliknya membutuhkan penyerahan atau bergantung kepada Allah, memiliki karakter yang serupa Kristus dan kemampuan untuk menerapkan kebenaran. ${ }^{23}$

\footnotetext{
${ }^{22}$ Ibid

${ }^{23}$ Neil T. Anderson, Discipleship Counseling, (Malang: Gandum Mas, 2011), 157
} 
Langkah-langkah proses konseling pemuridan adalah: pertama, pengaturan. Pengalaman telah mengajarkan bahwa seseorang dengan kecakapan memimpin dan kemampuan mengatur harus berfungsi sebagai direktur pelayanan konseling kemuridan secara keseluruhan. Proses konseling tersebut dimulai dari pemimpin yang bukan berarti menjadi penasehat terbaik atau guru bertalenta, tetapi memiliki kemampuan organisasional untuk memimpin pelayanan.

Kedua, pelatihan. Konselorkonselor awam perlu dilatih untuk menjadi pembimbing konselor pemuridan.

Ketiga, penyaringan. Proses ini adalah untuk mengetahui orang-orang yang terlibat dalam proses pemuridan konseling. Jika sampai salah mengizinkan orang masuk dalam pelayanan ini maka akan mejadi runtuhnya pelayanan konseling pemuridan.

Keempat, pertemuan-pertemuan kemerdekaan. Inti dari pelayanan ini adalah pertemuan-pertemuan kemerdekaan. Selama pertemuan ini, seorang pembimbing membawa konseli kepada pertobatan dengan menuntunnya menaikan doa pertobatan.

Kelima, kelompok-kelompok pendorong semangat. Proses mengikuti pertemuan-pertemuan kemerdekaan, para konseli sering membutuhkan dorongan dari sesama orang beriman untuk belajar bagaimana mempertahankan kemerdekaan mereka dan bertumbuh dalam anugerah Allah.

Keenam, dukungan doa dan jaringan doa. Doa adalah dasar rohani dari pelayanan ini. Mereka yang memiliki komitmen berdoa syafaat perlu menjadi perantara bagi setiap orang, termasuk para konseli, pembimbing, pemimpin kelompok dan para pengatur. ${ }^{24}$

Dampak dari pemuridan konseling adalah orang Kristen yang sungguhsungguh dapat menolong orang lain untuk mendapatkan kemerdekaan mereka di dalam Kristus. Konselor menolong orangorang Kristen menerima tanggung jawab hidup mereka sendiri dengan: meneguhkan identitas mereka di dalam Kristus, membuang kebohongan yang mereka percayai, memiliki kebenaran seperti yang dinyatakan dalam Firman Allah, dan mengatasi konflik pribadi dan konflik rohani yang menghalangi mereka dapat hidup produktif dalam Kristus. ${ }^{25}$

\section{Pemuridan Konstektual}

Pemuridan ini memakai nama Kelompok Tumbuh Bersama Kontekstual (KTBK) atau Contextual Bible Group (CBG). Pada Prinsipnya memiliki visi yaitu agar anggota KTBK menjadi serupa dengan Yesus. Misi KTBK adalalah: pertama, mendorong ornag percaya bertubuh ke arah kedewasaan penuh dalam Kristus. Kedua, memperlengkapi orang percaya dnegan pemahaman Alkitab Kontekstual. Ketiga, mengontrol orang percaya dalam ketaatan terhadap Firman Tuhan. Keempat, melipatgandakan KTBK dengan mendelagasi setiap anggota menjadi pemimpin KTBK baru.

Karakteristik KTBK adalah: alkitabiah, kontekstual, terfokus, interdependensi. ${ }^{26}$ Berdasarkan hal

\footnotetext{
${ }^{24}$ Ibid, 288-289

${ }^{25}$ Ibid, 157

${ }^{26}$ T. Haryono dan Yuliati, Pemuridan Kontekstual : Contextual Bible Group. (Surakarta, Yayasan Gamaliel, 2018), 60- 63.
} 
tersebut KTBK merupakan bentuk pemuridan yang meneladani pemuridan Yesus dan dilakukan secara kontinu supaya dapat diperlengkapi dan kemudian diutus.

Langkah-Langkah pemuridan KTBK/CBG adalah: pertama, belajar Firman Allah (learning). Untuk bertumbuh menuju kedewasaan penuh dan menjadi serupa dengan Kristus dibutuhkan pengajaran Firman Tuhan. Pengajaran Firman Tuhan harus disertai kerelaan dalam menaati otoritas Firman Tuhan. Dalam KTBK proses belajar dilakukan bersama dengan memahami Alkitab secara indukstif kontekstual.

Kedua, penyembahan dan doa. Penyembahan merupakan respon seseorang untuk memuji dan membesarkan nama Tuhan. Penyembahan mengingatkan perbuatan-perbuatan Tuhan dan kasih setia-Nya. KTBK tidak dapat dipisahkan dengan unsur penyemabahan karena unsur ini membuat anggota KTBK lebih mengenal Allah. Penyembahan dapat dilakukan melalui doa, puji-pujian, kidung, pembacaan Mazmur puji-pujian, dan puisi yang berisi puji-pujian.

Ketiga, persekutuan (fellowship). Persekutuan kasih yang terjadi di antara naggota KTBK akan menyaksikan kepada orang lain bahwa mereka benar-benar murid Kristus. Gereja mula-mula membentuk persekutuan karena mereka telah mengalami keselamatan dari Tuhan dan menyadari pentingnya persekutuan. Melalui persekutuan mereka terus bertumbuh kerohaniannya. Persekutuan dalam KTBK akan menolong semua anggota dapat saling mengasihi, saling melayani, saling membangun, saling memperhatikan, saling menasihati, mensharingkan kebutuhannya masingmasing, saling mengakui dosa-dosanya, saling menanggung beban, membesarkan hati orang lain dan saling mendoakan.

Keempat, pengutusan (Missions). KTBK terkait erat dengan pengutusan. Pengutusan adalah kesaksian anggota KTBK untuk pergi memberitakan Injil Yesus Kristus kepada orang-orang yang membutuhkannya. Melalui pengutusan ini anggota KTBK dapat mempraktikkan kasih dan kuasa Allah.

Keempat unsur di atas tidak dapat dipisahkan satu sama lain melainkan bekerja bersama-sama untuk mewujudkan tujuan KTBK. $^{27}$ Pemuridan KTBK dilakukan dengan learning, pujian dan doa, fellowship, dan missions. Pemuridan KTBK merupakan pemuridan yang lengkap untuk membekali setiap pelayan Tuhan untuk siap melayani di setiap panggilan pelayanan yang Tuhan sudah sediakan. KTBK menolong setiap pelayan Tuhan untuk mengerti setiap panggilannya melalui empat langkah-langkah tersebut.

Dampak yang diharapkan dari adanya KTBK adalah alumnus secara kontinyu dapat dibina imannya dengan mempelajari kebenaran Firman Tuhan. KTBK merupakan wadah pembinaan rohani yang sesuai untuk hal tersebut. Kebutuhan tersebut akan terjawab dalam KTBK. Ada beberapa hal yang mendasarinya, seperti: KTBK menggunakan pendekatan pendalaman Alkitab (PA) induktif kontekstual supaya anggota berpikir kritis dan kreatif untuk

\footnotetext{
${ }^{27}$ Ibid, 68- 69.
} 
memperoleh pengertian dan pesan asli dari teks Alkitab. ${ }^{28}$

\section{Kecenderungan Alumnus baru (Fresh Graduate) pada Masa Kini}

\author{
Pendekatan alumnus baru (Fresh \\ Graduate) masa kini kaitannya dengan \\ pencarian kerja.
}

Pekerjaan merupakan hal yang sulit di era globalisasi ini. Setiap individu pasti ingin mendapatkan pekerjaan yang sesuai dengan harapannya. Salah satu cara untuk mencapai hal tersebut adalah menempuh pendidikan perguruan tinggi dan mendapatkan gelar keilmuan. Namun, seiring bertambahnya jumlah populasi di Indonesia maka individu yang lulus dari perguruan tinggi pun terus meningkat, dan menyebabkan semakin sulitnya persaingan dalam mencari pekerjaan yang sesuai dengan kemampuan individu. Bahkan tidak jarang seorang lulusan tertentu bekerja tidak sesuai dengan bidang keahliannya, tidak mendapatkan pekerjaan yang layak, atau tidak mendapatkan pekerjaan apapun. Pada akhirnya sarjana baru akan mengalami kecemasan, bahkan takut merasa gagal apabila harus bersaing, tidak hanya dengan para pencari kerja lain yang sebidang keilmuan dan bukan hanya dari lulusan tahun ini, namun angkatan kerja sebelumnya juga. ${ }^{29}$ Berdasarkan hal tersebut persaingan kerja bagi seorang Alumnus baru sangat

\footnotetext{
${ }^{28} \mathrm{~T}$. Haryono dan Yuliati, Pemuridan Kontekstual : Contextual Bible Group. (Surakarta, Yayasan Gamaliel, 2018), 67

${ }^{29}$ Trisnawati, D. A. Peran self-efficacy dan persepsi citra almamater terhadap Ketakutan akan kegagalan pada para pencari kerja berstatus fresh graduate. Skripsi. (Malang: Program Studi Psikologi Universitas Brawijaya, 2013)
}

ketat. Alumnus baru ditutut untuk berani bersaing untuk tidak menjadi pengangguran secara intelektual.

Kasus lainnnya, terdapat juga lulusan perguruan tinggi yang merasa dirinya belum siap dan mampu dalam melangkah untuk memasuki dunia kerja, terutama pada lulusan baru. Di samping itu lapangan kerja yang tersedia sepertinya tidak mampu menampung seluruh pencari kerja yang jumlahnya terus meningkat. Situasi ini pada akhirnya menempatkan para pencari kerja dalam posisi yang kurang menguntungkan, karena pihak perusahaan akan semakin ketat dalam menyaring tenaga kerja dan pada akhirnya hanya bersedia merekrut tenaga kerja - tenaga kerja yang handal dan profesional.

Di tengah posisi tawar yang semakin rendah, para sarjana harus menghadapi persaingan yang sangat ketat untuk memperebutkan posisi pekerjaan yang tersedia. Akibatnya banyak pengangguran terdidik sampai pada tingkat titik jenuh. Hal ini diperparah dengan kondisi ekonomi yang tidak menentu seperti sekarang ini yang dicirikan lapangan kerja semakin sempit. ${ }^{30}$

Berdasarkan kasus di atas, motif pemenuhan hidup dan pekerjaan bagi alumnus lulusan baru menjadi pokok permasalahan dan titik yang sangat digumuli mereka. Alumnus baru harus bisa memenuhi kebutuhan hidupnya secara mandiri dan bisa terbebas dari sebutan pengangguran intelektual.

Berbagai penelitian mengenai alumnus baru dan kepentingannya dalam mencari pekerjaan dapat dilihat sebagai

\footnotetext{
${ }^{30}$ M. Atma Adhyaksa, Agus Rusgiyono, "Persepsi Dunia Kerja Terhadap Lulusan Fresh Graduate s1 Menggunakan Multidimensional Unfolding (Studi Kasus : Dunia Usaha Di Kabupaten Batang), Jurnal Statistika, Vol. 3, No. $1,2010,1$
} 
berikut: Self Esteem dan Optimisme Raih Kesuksesan karir pada Fresh Graduate Universitas diponegoro, ${ }^{31}$ Faktor-faktor yang mempengaruhi pailit pada masa muda (studi Kasus Fresh Graduate), ${ }^{32}$ Prediksi Minat Berwirausaha pada Fresh Graduate, ${ }^{33}$ dan sebagainya. Berbagai penelitian tentang Alumunus baru sangat berhubungan dengan pencarian pekerjaan dan bagaimana Alumnus baru untuk dapat melanjutkan hidup. Deskripsi tersebut menjelaskan bahwa kondisi Alumnus lulusan baru merupakan fase kritis dalam hal iman. Himpitan masalah ekonomi dan tugas panggilan pelayanan harus dipilih pada saat waktu-waktu tersebut.

Kecendrungan Alumnus Baru dalam Menanggapi Panggilan Pelayanan Berdasarkan Data Lapangan Alumnus dari Persekutuan Mahasiswa Kristen Surakarta

Data kecenderungan alumnus baru dalam kaitannya dengan panggilan pelayanan dilakukan dengan wawancara. Pengumpulan data dilakukan dengan proses wawancara dibatasi pada alumnus dari mahasiswa yang pernah melayani di PMK Surakarta.

\footnotetext{
${ }^{31}$ Andi Rahmalia Putri, Frieda Nrh, "Self Esteem Dan Optimisme Raih Kesuksesan Karir Pada Fresh Graduate Fakultas Teknik Universitas Diponegoro," Jurnal Empati, Vol 4, No 4, 2015. 15.

${ }^{32}$ Uma Murthy \& Paul Anthony Mariadas, "Factors Affecting Fresh Graduate Bankruptcy At Young Age: The CaseOf Fresh Graduates In Kota Damansara," International Journal of Business and Management, Vol 12, No 12, 2017, 194.

${ }^{33}$ Jixia Tu et al, "Predict the Entrepreneurial Intention ofFresh Graduate Students Based on an AdaptiveSupport Vector Machine Framework," Jurnal Hindawi : Mathematical Problem in Engineering, 2019, 1.
}

Pertanyaan pertama pada proses wawancara ini yaitu: Apakah anda dulu aktif melayani saat mahasiswa, dan melayani dimana, dan apa komitmen anda? Pertanyaan ini bertujuan untuk mendapatkan data mengenai akuntabilitas responden sehingga bisa memberikan jawaban atas fenomena ingkarnya alumnus baru terhadap panggilan.

$$
\text { Dari data tersebut didapatkan }
$$
bahwa seluruh responden merupakan pelayan saat mahasiswa dengan komitmen supaya berkembang imannya, melayani ketika kuliah, jika ada waktu tetap melayani dan memberi diri untuk pelayanan Tuhan. ${ }^{34}$

Data kedua dari wawancara diharapkan dapat mengerti secara real pergumulan yang dihadapi oleh alumnus baru. Pertanyaan yang digunakan adalah: Bagaimana pergumulan yang dihadapi oleh alumnus baru?

Berdasarkan data yang didapat, permasalahan riil yang dihadapi oleh para alumnus baru adalah sebagai berikut: gengsi dalam mencari kerja sehingga tidak mendapatkan pekerjaan, pencarian pekerjaan, menyenangkan orang tua dengan hidup mandiri, dan pergumulan untuk studi lanjut. ${ }^{35}$

Permasalahan yang cukup kompleks dan utama adalah keterkaitan dengan pekerjaan dan pemenuhan hidup dari setiap alumnus baru.

Data ketiga dari wawancara diharapkan mendapatkan data kecenderungan komitmen pelayanan alumnus baru dari mahasiswa PMKS terkait panggilan

\footnotetext{
${ }^{34}$ Disarikan dari wawancara dengan Alumnus dari Mahasiswa yang pernah melayani di PMKS

${ }^{35}$ Ibid
} 
pelayanannya. Pertanyaan wawancara adalah: Bagaimana kecenderungan komitmen pelayanan teman-teman alumnus baru setelah lulus?

Jawaban yang didapatkan adalah bervariasi diantaranya adalah: ada alumnus yang memang tetap melayani ketika lulus, ada beberapa alumunus yang mencari tempat pelayanan, dan yang terakhir karena keadaan membuat alumnus sukar untuk melayani sehingga pada akhirnya tidak melayani. ${ }^{36}$ Berdasarkan hal tersebut jawaban bervariasi, namun ada beberapa kasus bahwa alumnus baru karena pergumulan pekerjaannya hingga meninggalkan komitmen panggilan pelayanannya.

Data keempat dari wawancara di harapkan mendapatkan kasus nyata dari kecenderungan alumnus baru yang akhirnya meninggalkan panggilan pelayanannya. Pertanyaan wawancara yang digunakan adalah: Ceritakanlah kasus khusus alumnus baru yang karena pergumulannya meninggalkan tugas panggilan pelayannnya!

Hasil dari wawancara tersebut diantaranya adalah: karena kendala lingkungan baru, bahasa baru di penempatan pekerjaan membuat alumnus baru tidak melayani, waktu pekerjaan yang sangat padat, dan tempat kerja dan pelayanan yang jauh. ${ }^{37}$ Berdasarkan data wawancara tersebut didapatkan hasil bahwa ada beberapa kasus mahasiswa yang meninggalkan komitmen pelayanannya karena permasalahan-permasalah-

\footnotetext{
${ }^{36}$ Disarikan dari wawancara dengan Alumnus dari Mahasiswa yang pernah melayani di PMKS ${ }^{37}$ Ibid
}

an pekerjaan yang menerpa para alumnus baru.

\section{Analisis}

Persamaan dan perbedaan Petrus dan Alumnus Baru pada masa kini.

Petrus dan alumnus baru pada masa kini memliki latar belakang berbeda. Petrus dari kalangan bukan intelektual sedangkan alumnus baru merupakan kaum intelektual. Petrus merupakan tenaga kerja terlatih dan berpengalaman, sedangkan alumnus baru adalah tenaga kerja baru dan tidak memiliki pengalaman. Keduanya memiliki kesamaan dalam permasalahan yang dihadapi.

Saat dipanggil pertama kali Petrus bekerja untuk memenuhi kebutuhan hidup dan setelah penyaliban ia kembali kepada pekerjaannya. Alumnus baru juga mencari pekerjaan untuk dapa melakukan pemenuhan kebutuhan hidupnya. Keduanya didasari dari motif ekonomi membuat Petrus kembali kepada pekerjaan sekuler dan meninggalkan panggilan pelayannnya. Hal ini juga terjadi pada kecenderungan beberapa alumnus baru yang oleh karena masalah pekerjaan mereka undur dan meninggalkan panggilan pelayanan mereka.

Persamaan dan perbedaan sarana yang dilakukan untuk mengarahkan pada panggilan pelayanan.

Sarana yang digunakan untuk mengarahkan pada panggilan pelayanan yaitu dengan menggunakan pemuridan. Yesus memuridkan Petrus secara kontinyu. Proses ini diawali dari pemanggilan Petrus pada Lukas 5:1-11 dan pemanggilan kembali pada Yohanes Pasal 21:1-23. Sarana yang digunakan untuk alumnus 
baru untuk kembali pada panggilan pelayanannya adalah juga dengan pemuridan.

Tujuan pemuridan untuk bertumbuh dewasa serupa Yesus. Perbedaan dari kedua pemurian ini adalah bahwa pemuridan masa kini bertujuan untuk serupa Yesus dengan memakai sumber dari kebenaran Alkitab. Pemuridan bagi Petrus dipimpin oleh Tuhan Yesus dan juga tetap berdasarkan pada kitab suci.

Analisis model Pemuridan Konseling Yesus dengan pemuridan konseling dan KTBK bagi konteks Alumnus yang mengingkari panggilan pelayannnya

\begin{tabular}{|c|c|c|}
\hline $\begin{array}{c}\text { Pemuridan } \\
\text { Konseling } \\
\text { Yesus }\end{array}$ & $\begin{array}{c}\text { Pemuridan } \\
\text { Konseling dan } \\
\text { KTBK }\end{array}$ & Sintesis \\
\hline $\begin{array}{l}\text { Prinsip Yesus } \\
\text { adalah } \\
\text { mengajak } \\
\text { orang dalam } \\
\text { pekerjaan } \\
\text { pelayannya } \\
\text { dan } \\
\text { memberikan } \\
\text { providensia } \\
\text { penuh. }\end{array}$ & $\begin{array}{l}\text { Prinsip } \\
\text { Pemuridan } \\
\text { konseling } \\
\text { adalah } \\
\text { mengajak } \\
\text { setiap orang } \\
\text { menuju } \\
\text { kemerdekaan } \\
\text { dalam Kristus. } \\
\text { Prinsip KTBK } \\
\text { adalah } \\
\text { bertumbuh } \\
\text { menjadi serupa } \\
\text { ke-arah } \\
\text { Kristus. }\end{array}$ & $\begin{array}{l}\text { Pemuridan } \\
\text { Konseling } \\
\text { dengan } \\
\text { mengedepan- } \\
\text { kan } \\
\text { kontiunuitas } \\
\text { pemuridan } \\
\text { untuk } \\
\text { bertumbuh ke } \\
\text { arah Kristus } \\
\text { dan } \\
\text { memberikan } \\
\text { providensia } \\
\text { Allah dengan } \\
\text { membawa } \\
\text { setiap murid } \\
\text { merasakan } \\
\text { kemerdekaan } \\
\text { sesungguhnya } \\
\text { dalam Yesus. }\end{array}$ \\
\hline $\begin{array}{l}\text { Langkah- } \\
\text { langkah } \\
\text { Yesus } \\
\text { dengan } \\
\text { menggu- } \\
\text { nakan } \\
\text { penerimaan, }\end{array}$ & $\begin{array}{l}\text { Langkah } \\
\text { Permuidan } \\
\text { Konseling } \\
\text { adalah } \\
\text { pengaturan, } \\
\text { pelatihan, } \\
\text { penyaringan, }\end{array}$ & $\begin{array}{l}\text { Langkah yang } \\
\text { diutamakan } \\
\text { adalah } \\
\text { Penerimaan } \\
\text { pemuridan bagi } \\
\text { seluruh } \\
\text { alumnus baru }\end{array}$ \\
\hline
\end{tabular}

\begin{tabular}{|c|c|c|}
\hline $\begin{array}{l}\text { pendampi- } \\
\text { ngan dan } \\
\text { pengutusan }\end{array}$ & $\begin{array}{l}\text { pertemuan, } \\
\text { kelompok- } \\
\text { kelompok } \\
\text { pendorong } \\
\text { semangat, } \\
\text { dukungan doa } \\
\text { Langkah- } \\
\text { langkah KTBK } \\
\text { learning, } \\
\text { penyembahan } \\
\text { dan doa, } \\
\text { Fellowship, } \\
\text { pengutusan. }\end{array}$ & $\begin{array}{l}\text { baik mereka } \\
\text { yang dalam } \\
\text { keadaan baik } \\
\text { atau tidak baik, } \\
\text { untuk dibawa } \\
\text { mempelajari } \\
\text { Firman Tuhan } \\
\text { (learning), } \\
\text { memiliki } \\
\text { fellowship } \\
\text { (wujud } \\
\text { providensia } \\
\text { Allah) dan siap } \\
\text { untuk diutus } \\
\text { bagi pelayanan. }\end{array}$ \\
\hline $\begin{array}{l}\text { Dampak } \\
\text { Pemuridan } \\
\text { Konseling } \\
\text { adalah } \\
\text { membawa } \\
\text { kembali } \\
\text { simon atau } \\
\text { petrus untuk } \\
\text { kembali } \\
\text { menanggapi } \\
\text { panggilan } \\
\text { pelayannyan. }\end{array}$ & $\begin{array}{l}\text { Dampak } \\
\text { Pemuridan } \\
\text { Konseling } \\
\text { adalah } \\
\text { menolong } \\
\text { orang lain } \\
\text { untuk } \\
\text { mendapatkan } \\
\text { kemerdekaan- } \\
\text { nya dalam } \\
\text { Yesus. } \\
\text { Dampak } \\
\text { pemuridan } \\
\text { Kontekstual } \\
\text { adalah secara } \\
\text { kontinu terbina } \\
\text { imannya }\end{array}$ & $\begin{array}{l}\text { Dampak yang } \\
\text { diharapkan } \\
\text { adalah } \\
\text { mendapatkan } \\
\text { jawaban atas } \\
\text { setiap } \\
\text { permasalahan } \\
\text { (kemerdekaan), } \\
\text { kembali pada } \\
\text { panggilan } \\
\text { pelayanan, dan } \\
\text { kontinu terbina } \\
\text { imannya. }\end{array}$ \\
\hline
\end{tabular}

Pemuridan Konseling bagi Alumnus Perguruan Tinggi Lulusan Baru (Fresh Graduate)Yang Mengingkari Panggilan Pelayanannya

Berdasarkan analisis $\mathrm{di}$ atas di dapatkan model pemuridan konseling bagi alumnus perguruan tinggi lulusan baru (Fresh Graduate) yang mengingkari panggilan pelayanannya. Hal tersebut di deskripsikan dalam tiga hal yaitu: prinsip, langkah-langkah, dan dampak pemuridan konseling dalam kaitanya dengan konse- 
ling komitmen ulang untuk kembali melayani bagi alumnus baru pada masa kini.

\section{Pertama, Prinsip Pemuridan Konseling bagi Alumnus Baru yang Mengingkari Panggilan Pelayanan}

Prinsip pemuridan konseling bagi alumnus baru adalah mengedepankan kontinyuitas pemuridan untuk bertumbuh ke arah Kristus dan memberikan providensia Allah dengan membawa setiap murid merasakan kemerdekaan sesungguhnya dalam Yesus. Prinsip ini sesuai dengan apa yang Tuhan Yesus kerjakan bahwa Yesus memberikan providensia nyata ketika Simon Petrus mengalami permasalahan. Pemuridan konseling sebagai providensia Ilahi bertujuan untuk membawa setiap alumnus baru merasakan kemerdekaan dari masalah. Sarana yang digunakan adalah dnegan menggunakan pemuridan konseling.

Penekanan prinsip ini adalah untuk bertumbuh dan merdeka, sehingga proses pemuridan bertujuan untuk bertumbuh dalam iman dan merdeka. Ini bagian dari konseling untuk mengatasi setiap masalah bersama Yesus. Bertumbuh dalam iman dan proses kemerdekaan ini harus dilakukan secara kontinyu.

Prinsip ini bersama-sama dikerjakan baik oleh pemimpin pemuridan dan anggota permuridan dengan hubungan interdependensi. Anggota dan pemimpin saling bergantung, saling menguatkan, saling bertumbuh dalam iman untuk serupa sampai Yesus.

\footnotetext{
Kedua, Langkah-langkah Pemuridan Konseling bagi Alumnus Baru yang Mengingkari Panggilan Pelayanan
}

Langkah-langkah pemuridan konseling bagi alumnus baru adalah penerimaan pemuridan bagi seluruh alumnus baru, baik mereka yang dalam keadaan baik atau tidak baik, untuk dibawa mempelajari Firman Tuhan (Learning), memiliki fellowship (wujud providensia Allah) dan siap untuk diutus bagi pelayanan.

Langkah pertama adalah penerimaan. Alumnus diterima dalam kelompok-kelompok pemuridan yang disebut KTBK. Penerimaan ini didasarkan dari kebutuhan, latar belakang dan tanpa ada paksaan sehingga melihat kemauan dari alumnus baru untuk mengikuti proses pemuridan melalui KTBK.

Langkah kedua adalah learning. Setelah masuk dalam KTBK-KTBK para alumnus bersama-sama berkomitmen untuk mempelajari kebenaran Firman Tuhan. Firman Tuhan merupakan makanan rohani dan jawaban untuk setiap pergumulan yang sedang dihadapi. Firman Tuhan secara kontinyu dipelajari dan dimengerti. Bagian ini mungkin terlihat menjemukan, namun pada bagian ini dibuat sekreatif mungkin dengan bahanbahan KTBK yang sudah ada.

Pembelajaran akan Firman Tuhan akan sangat berdampak pada kehidupan baik fisik maupun mental dari seorang alumnus. Kebenaran firman Tuhan akan mendorong alumnus untuk semakin bertumubuh ke arah Kristus.

Langkah ketiga adalah memiliki fellowship sebagai wujud providensia Allah. Setelah mempelajari Firman Tuhan tidak langsung setiap pergumulan hidup seorang alumnus mendapatkan jalan keluar. Tetapi paradigma dan pengambilan keputusan dalam mengahadapi masalah 
akan berbeda. Hal itu harus didukung oleh adanya kelompok-kelompok yang mengedepankan fellowship. Kelompok ini saling menguatkan, memberikan bantuan dan menolong apapun permasalahan yang dihadapi oleh setiap anggota KTBK. Hubungan yang ditekankan adalah hubungan interdependesi yaitu saling. Setiap anggota pemuridan saling satu dengan yang lainnya untuk mewujudkan providensia Allah dalam kehidupan mereka masing-masing.

Langkah terakhir adalah pengutusan, yaitu bahwa setelah dimuridkan dan konseling untuk merdeka di dalam Yesus. Setiap anggota harus berani berkomitmen melayani, setidaknya juga dengan memuridkan orang lain. Pengutusan menjadi goal apakah langkah pertama, kedua, dan ketiga tersebut berhasil atau tidak. Alumnus baru yang telah merdeka dan terbebas dari masalahnya dimotivasi untuk ikut dalam panggilan pelayanan. Program pengutusan dilakukan seperti Yesus mengutus yang pertama ataupun yang terakhir kalinya kepada Petrus. Kesabaran Yesus untuk memanggil kembali Petrus dalam usaha mengingatkan panggilan pelayannya juga perlu dimiliki oleh para pemimpin pemuridan konseling.

Empat langkah tersebut digunakan dalam proses pemuridan konseling bagi alumnus baru yang mengingkari panggilan pelanyannya. Langkah-langkah tersebut harus dilakukan dengan terus menerus dan diharapkan adanya multiplikasi dari pelayanan tersebut.

Ketiga, Dampak Yang Diharapkan dari Pemuridan Konseling bagi Alumnus Baru yang Mengingkari Panggilan Pelayanan
Dampak yang diharapkan dari proses pemuridan konseling ini adalah mendapatkan jawaban atas setiap permasalahan hidup (kemerdekaan), kembali pada panggilan pelayanan, dan kontinu terbina imannya. Melalui dampak ini seluruh alumnus diharapkan akan terus melayani Tuhan sampai meninggal. Alumnus secara kontinyu terbina imannya dan terus secara efektif dapat membina alumnus yang lainnya yang menghadapi permasalahan yang sama ataupun tidak. Secara global damak ini akan menolong kehidupan bagi setiap alumnus secara langsung dalam mengahadapi setiap permasalah kehidupannya.

\section{Kesimpulan dan Saran}

Berdasarkan hal di atas dapat disimpulkan bahwa melalui penelitian ini didapatkan model pemuridan konseling bagi alumnus perguruan tinggi lulusan baru (fresh Graduate) yang mengingkari panggilan pelayannya adalah: pertama, Prinsip: bertumbuh ke arah Kristus dan merdeka di dalam Kristus. Kedua, langkah-langkah pemuridan konseling yang terdiri atas penerimaan, learning, fellowship, dan pengutusan. Ketiga, adalah dampak yang diharapkan yaitu untuk alumnus baru mendapatkan jawaban atas permasalahan hidup dan imananya terus dibina di dalam pemuridan.

Saran dari penelitian ini adalah perlu dilakukan penelitian lanjutan secara kuantitatif berapa presentase model ini terhadap komitmen ulang para alumnus baru (fresh graduate) dalam menanggapi panggilan pelayanannya.

\section{Daftar Pustaka}


Amallia, Bella, "Dampak Asean Economic Community (Aec) Terhadap Tenaga Kerja Indonesia Di Singapura." Jurnal JOM FISIP, Vol 4, No 2, 2017.

Adhyaksa,M. Atma, Agus Rusgiyono, "Persepsi Dunia Kerja Terhadap Lulusan Fresh Graduate s1 Menggunakan Multidimensional Unfolding (Studi Kasus : Dunia Usaha Di Kabupaten Batang), Jurnal Statistika, Vol. 3, No. 1, 2010.

Anderson, Neil T., Discipleship Counseling, (Malang: Gandum Mas, 2011), 157

Don Fleming, Bridge Way Bible Commentary, Brisbane: Bridge Way Publication, 2005.

Arigiyati,Tri Astuti, Annis Deshinta Ayuningtyas, "Efektivitas Model Reciprocal Teaching BerdasarkanMotivasi Belajar Statistika Pada MahasiswaProdi Pgsd Fkip Ust"eminar dan call For Papers, Dies Natalis Universitas Sarjanawiyata Tamansiswa ke-60, 2015.

D. A., Trisnawati, Peran self-efficacy dan persepsi citra almamater terhadap Ketakutan akan kegagalan pada para pencari kerja berstatus fresh graduate. Skripsi. Malang: Program Studi Psikologi Universitas Brawijaya, 2013.

Delasari, Yulia, "Dampak Pasar Bebas Asean (Mea) Terhadap Pertumbuhan Umkm Provinsi Riau (Industri Makanan Bolu Kembojo)," Jurnal JOM Fisip, Vol 5, No 2, 2018

Haryono, T. dan Yuliati, Pemuridan Kontekstual : Contextual Bible
Group. Surakarta, Yayasan Gamaliel, 2018.

Henry, Matthew Commentary on The Whole Bible Volume V (Matthew to John), Grand Rapid, MI : Christian Classics Ethereal Library, 2000.

Henry, Matthew, Matthew Henry's Concise Commentary on The Bible, Grand Rapids, MI: Christian Classics Ethereal Library, 2005.

Jackson, R.and G. Sorensen. Pengantar Studi Hubungan Internasional (terjemahan dari Introduction to International Relations). Yogyakarta: Pustaka Pelajar, 2009.

Jamieson, Robert, et al, Commentary Critical and Explanatory on the Whole Bible, Grand Rapid, MI : Christian Classics Ethereal Library,2009.

Kurniawaty Fitri, "Pengaruh Jenjang Karir dan Tantangan Pekerjaan Terhadap Minat Fresh Graduate FKIP Universitas Riau pada Profesi Sales," Jurnal Sosial Ekonomi Pembangunan, Vol 10, 2013.

Putri, Andi Rahmalia, Frieda Nrh, "Self Esteem Dan Optimisme Raih Kesuksesan Karir Pada Fresh Graduate Fakultas Teknik Universitas Diponegoro," Jurnal Empati, Vol 4, No 4, 2015.

Rofiq,Atep Abdu, "Menakar Pengaruh Masyarakat EkonomiAsean 2015 Terhadap PembangunanIndonesia,"SalamJur nal Filsafat dan Budaya Hukum, 2014.

Sejati, Nurmantika Wiji dan Rahmawati Prihastuti, “ Tingkat Kecemasan Sarjana Fresh Graduate menghadapi Persaingan Kerja dan 
Meningkatnya Pengangguran

Intelektual," Jurnal Intuisi, Vol 4, No 3, 2012.

Setuju, "Penguatan Karakter Mahasiswa dalam Menghadapi MEA", Seminar dan call For Papers, Dies Natalis Universitas Sarjanawiyata Tamansiswa ke-60, 2015.

$\mathrm{Tu}$, Jixia et al, "Predict the

Entrepreneurial Intention ofFresh

Graduate Students Based on an AdaptiveSupport Vector Machine Framework," Jurnal Hindawi : Mathematical Problem in Engineering, 2019.

Uma Murthy \& Paul Anthony Mariadas, "Factors Affecting Fresh Graduate Bankruptcy At Young Age: The CaseOf Fresh Graduates In Kota Damansara," International Journal of Business and Management, $\mathrm{Vol}$ 12, No 12, 2017. 